\title{
Standardization of a SYBR Green Based Real-Time PCR System for Detection and Molecular Quantification of Babesia bovis and $B$. bigemina in Water Buffaloes (Bubalus bubalis)
}

\author{
Dasiel Obregón ${ }^{1,2,}$, Marcio D. Rabelo ${ }^{3}$, Rodrigo Giglioti ${ }^{3,4}$, Thalita B. Bilhassi ${ }^{3,4}$,
} Thalita A. Néo $0^{3,5}$, Belkis Corona ${ }^{2}$, Pastor Alfonso ${ }^{2}$, Rosangela Z. Machado ${ }^{4}$ and Marcia C.S. Oliveira ${ }^{3}$

${ }^{1}$ Universidad Agraria de La Habana, Carretera de Tapaste y Autopista Nacional, CP 32700, Apartado Postal 18-19, San José de Las Lajas, Mayabeque, Cuba

${ }^{2}$ Centro Nacional de Sanidad Agropecuaria, Carretera de Jamaica y Autopista Nacional, CP 32700, Apartado Postal 10, San José de Las Lajas, Mayabeque, Cuba

${ }^{3}$ Embrapa Pecuária Sudeste, Rodovia Washington Luiz, km 234 - CEP 13560-970, Caixa Postal 339, São Carlos, São Paulo, Brasil

${ }^{4}$ Universidade Estadual Paulista, Via de Acesso Prof. Paulo Donato Castelane, S/N - Vila Industrial, 14884900, Jaboticabal, São Paulo, Brasil

${ }^{5}$ Universidade Federal de São Carlos, Rodovia Washington Luís, km 235 - CEP 13565-905, Caixa Postal 310, São Carlos - São Paulo - Brasil

\begin{abstract}
Water buffalo (Bubalus bubalis) is a potential reservoir for Babesia bovis and B. bigemina in tropical regions, but the epidemiological evidence of their reservoir competence is limited, especially due to the lack of diagnostic tests capable of detecting and quantifying the low-level parasitemia present in the carrier animals. In this paper we present the standardization process of a SYBR Green based real-time PCR system (qPCR), consisting of two single qPCR assays, for the detection and quantification of $B$. bovis and/or B. bigemina. Both assays were optimized in similar protocols, including reagent concentrations and thermocycling parameters, so it is possible its use as a multiple qPCR in a single run. Both single assays showed a suitable analytical performance, especially by allowing detection of a greater number of carrier animals when compared with nested PCR assays (nPCR) against a reference panel of 60 DNA samples extracted from blood of both, infected- and non-infected buffaloes. Furthermore, a mathematical algorithm to convert the GPCR outcomes in percent of infected red blood cell was used, and was found that the estimated parasitemia in carrier buffaloes within the reference sample panels were close to those described in carrier cattle. This method could be a useful tool for epidemiological studies on the participation of the bubaline specie in the epidemic process of bovine babesiosis.
\end{abstract}

Keywords: Babesia bovis, B. bigemina, water buffalo, parasitemia, qPCR, standardization.

\section{INTRODUCTION}

Bovine babesiosis is one of the main constraints for livestock in tropical and subtropical regions of the world, caused by the tick-borne protozoa Babesia bovis, $B$. bigemina and $B$. divergens (Apicomplexa: Babesiidae). B. bovis and $B$. bigemina are widespread in Latin America, Africa, Australia, and Asia, and they generally occur as mixed infections, whereas $B$. divergens is only found in the northeast of Europe and Tunisia [1, 2]. The cattle is the maintenance host of $B$. bovis and $B$. bigemina; however the animals of the subspecie Bos taurus taurus are very susceptible, whereas those of $B$. $t$. indicus are more resistant and, generally, remain as carrier hosts for a long time, especially for $B$. bovis [3-5].

*Address correspondence to this author at the Universidad Agraria de La Habana, Carretera de Tapaste y Autopista Nacional, CP 32700, Apartado Postal 18-19, San José de Las Lajas, Mayabeque, Cuba; Tel: 53047 862752; Fax: 53047 861104; E-mail: dasielogv@gmail.es
Epidemiological studies in endemic areas showed that other ruminants may be carriers of $B$. bovis and $B$. bigemina, such as the white-tailed deer (Odocoileus virginianus) [6], the impala (Aepyceros melampus), the african buffalo (Syncerus caffer) [7], and the water buffalo (Bubalus bubalis) [8]. However, no evidence of infection maintenance and cross-species transmission (reservoir competence) have been found in these host populations, so that they could be incidental hosts [9]. Specifically, water buffaloes are a potential reservoir because of the frequent coexistence with cattle in livestock ecosystems [10,11] and as it has been demonstrated that these ruminants are able to sustain the complete tick life cycle of $R$. microplus $[12,13]$.

On the other hand, water buffalo is resistant to babesiosis, and when infected it will develop a subclinical form of the disease (carrier host) [11, 14], likely with low levels of parasitemia because they are undetectable by Giemsa-stained blood smears $[8,10]$. 
However, no quantitative evidence of parasitemia and infectiousness are found in buffaloes. In carrier cattle the parasitemia by $B$. bovis and $B$. bigemina remains below $0.01 \% \mathrm{IRBC} / \mathrm{mL}$ (Percent infected red blood cells per $\mathrm{mL}$ ), which is sufficient to infect tick populations $[2,15]$.

Identifying the hosts that contribute most to the infection of vectors population is crucial for understanding the transmission dynamics of vector borne diseases, as well as for planning intervention strategies targeting the relevant infected host groups [16]. The parasitemia is an important factor of the host reservoir competence on vector borne pathogens, influencing their contribution (host infectiousness profile) to the infected vector population [17]. The Giemsa-stained blood smears is a conventional method used to determine parasitemia in clinically infected cattle, but this test has low analytical sensitivity and is ineffective in carrier animals $[15,18,19]$.

The introduction of PCR method allows detection of carrier cattle infected with $B$. bovis and $B$. bigemina, especially $\mathrm{nPCR}$ assays with a lower limit of detection on $0.0000001 \% \mathrm{IRBC} / \mathrm{mL}[2,15]$. Subsequently, the real-time PCR (qPCR) techniques have improved the diagnosis of bovine babesiosis and allowed to quantify the infection levels in carrier animals, with high sensitivity, specificity and analytical accuracy [20-22].

However, the effectiveness of qPCR in the diagnosis and quantification of these protozoa in other host species has not been evaluated. In addition, the estimates of infection levels on carrier cattle are based on parasites/ $\mu \mathrm{L}[21,23]$, which require an additional procedure enabling the transformation of $\mathrm{qPCR}$ outcomes into percent IRBC/mL. The present work was carried out with the objective of standardizing a SYBR Green based real-time PCR system for the detection and quantification of $B$. bovis and B. bigemina in carrier hosts, especially in water buffaloes.

\section{MATERIALS AND METHODS}

\section{qPCR Assays}

This work was conducted at the Laboratory of Animal Health, Embrapa Pecuária Sudeste, São Carlos, São Paulo, Brazil. A SYBR Green based realtime PCR system was used; it consisted of two single assays, one for $B$. bovis and the other for B. bigemina. The primers used were those described by Buling et al. [22], which amplify 88bp fragments of the mitochondrial cytochrome b gene (mt-Cytb). For B. bovis: cbosg forward. 5'-TGTTCCTGGAAGCGTTGATTC-3' and cbosg Reverse. 5'-AGCGTGAAAATAACGCATTGC-3'; for $B$. bigemina: cbisg forward. 5'-TGTTCCAGGAGA TGTTGATTC-3' and cbisg reverse. 5'-AGCATGGAAAT AACGAAGTGC-3'. Primer specificity was verified with the sequences available in GenBank by using the search tool BLASTn (http://blast.ncbi.nlm.nih.gov/ blastn).

The qPCR reactions were initially performed in a final volume of $15 \mu \mathrm{L}$, with $7.5 \mu \mathrm{L}$ of the commercial mix (2X) Lumino SYBER $\circledast$ Green qPCR Ready Mix (Sigma), $1 \mu \mathrm{L}$ of each primer $(10 \mu \mathrm{M}), 2 \mu \mathrm{L}$ of DNA, and nuclease-free water (Promega). The same amplification program was used for both assays: an initial cycle of $95^{\circ} \mathrm{C} / 5 \mathrm{~min}$, followed by 40 cycles of $95^{\circ} \mathrm{C} / 5 \mathrm{seg}$, and $60^{\circ} \mathrm{C} / 45 \mathrm{seg}$ for hybridization and extension jointly. In addition, a melting curve was included to verify the specificity of the amplicons, between $65^{\circ} \mathrm{C}$ and $95^{\circ} \mathrm{C}$ with increments of $0.5^{\circ} \mathrm{C} / 5$ seg. A thermocycler CFX Real-Time PCR Detection Systems (BioRad) and PCR Low-Profile 8Tube strips (BioRad) were used.

\section{Standard Test Method for Comparison}

A nPCR system targeting the gene $18 S$ rRNA of $B$. bovis and $B$. bigemina, previously reported by Guerrero et al. [24] but with modifications, was used as reference (hereinafter "standard test"). Briefly, the PCR reactions were performed in $25 \mu \mathrm{L}$, which contained $12.5 \mu \mathrm{L}$ of commercial mix (2X) Jump Start RED TaqReady Mix (Sigma Aldrich), $1.0 \mu \mathrm{L}(10 \mu \mathrm{M})$ of each primer, $2 \mu \mathrm{L}$ of DNA, and nuclease-free water. Subsequently, the $\mathrm{nPCR}$ reactions were performed in $20 \mu \mathrm{L}$, which contained $10 \mu \mathrm{L}$ of (2X) Jump Start RED TaqReady Mix (Sigma Aldrich), $1.0 \mu \mathrm{L}(10 \mu \mathrm{M})$ of each primers, $1 \mu \mathrm{L}$ of the PCR product as template DNA, and nuclease-free water (Promega).

\section{DNA for Positive and Negative Controls}

Genomic DNA from "Jaboticabal" isolate of $B$. bovis and $B$. bigemina was used as a positive control (hereinafter "positive control"). The DNA was extracted with the commercial kit llustra Blood Genomic Prep Mini Spin (GE Healthcare) from $300 \mu \mathrm{L}$ of blood obtained from artificially infected splenectomized calves sampled at peak parasitemia, according to Machado et al. [25]. The genomic DNA from blood of newborn water buffalo calf free of Babesia spp. was used as the negative control.

Also, a reference sample panel (hereinafter "reference samples") was used for each assay for 
comparing the outcomes with the standard test method, according to the recommendations by the World Organization for Animal Health [26]. Each panel had 60 DNA samples, 30 of them were nPCR-positive and $30 \mathrm{nPCR}$-negative. The DNA samples were extracted from the blood of water buffaloes randomly selected from farms in western Cuba, as described by Obregón et al. [8]. DNA extraction was performed from $300 \mu \mathrm{L}$ of blood by using the WIZARD Genomic DNA Purification Kit (Promega).

\section{Standard Curves}

Initial qPCR reactions with positive controls as target DNA (ten replicates) were performed for each assay, and the resulting amplicons (88pb) were used to construct the standard curve for each assay. The amplicons were directly purified from the qPCR product using the commercial kit Pure Link PCR Purification Kit (Invitrogen) and cloned into the plasmid pGEM®-T Easy Vector Systems (Promega) (3000pb) as described by Bilhassi et al. [23].

Afterwards, the concentration of the recombinant plasmid were determined using a Nanodrop 1000 v.3.5 spectrophotometer (Thermo Fisher Scientific), and the

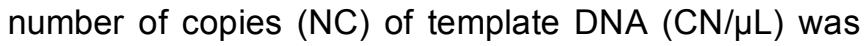
estimated by the equation described by $\mathrm{Ke}$ et al. [27]: $\mathrm{CN} / \mu \mathrm{L}=$ Conc. $(\mathrm{g} / \mu \mathrm{L}) \times \mathrm{N}_{\mathrm{A}} / \mathrm{MW}(\mathrm{g} / \mathrm{mol})$, where $\mathrm{NA}$ is Avogadro constant $\left(6.022 \times 10^{23} \mathrm{copy} / \mathrm{mol}\right)$ and $\mathrm{MW}$ is the molecular weight of each pair of nucleotides (660) multiplied by the molecular weight of the recombinant plasmid (3088bp). Subsequently, ten-fold serial dilutions (from $10^{-1}$ to $10^{-10}$ ) were made.

\section{Optimization of qPCR Reactions}

The critical parameters were simultaneously optimized in the two assays. These were the hybridization temperature $\left(63^{\circ} \mathrm{C}, 60^{\circ} \mathrm{C}\right.$, and $\left.57^{\circ} \mathrm{C}\right)$, time of hybridization and extension (30seg, 45seg, and $60 \mathrm{seg})$, concentration of primers $(0.1 \mu \mathrm{M}, 0.2 \mu \mathrm{M}$, $0.4 \mu \mathrm{M}, 0.6 \mu \mathrm{M}$, and $0.8 \mu \mathrm{M})$, and volume of template DNA $(1 \mu \mathrm{L}, 2 \mu \mathrm{L}$ and $4 \mu \mathrm{L})$. The $10^{-2}-10^{-8}$ dilutions of the standard curve were used as template DNA.

Linearity of the results of the qPCR assays was assessed from the efficiency of the PCR reactions of the standard curves and by the parameters: slope, $y$ intercept, and the regression coefficient $\left(R^{2}\right)$. In addition, ten samples from carrier buffaloes for each hemoparasite were tested to verify that they presented the quantitative cycle $(\mathrm{Cq})$ within the range of the standard curve, as recommended by Mueller et al. [28].

\section{Evaluation of Analytical Performance}

The analytical performance of the assays was evaluated following the methodology proposed by the OIE for standardization of molecular assays $[29,30]$. The intra- e inter-assay repeatability was measured from the coefficient of variation (CV) of the $\mathrm{Cq}$ values in the standard curve. Ten trials of each assay, with each standard dilutions tested in triplicate, were included in the analysis. The analytical specificity (Asp) was determined according to the capacity of differentiating between $B$. bovis and $B$. bigemina, and host genomic DNA (exclusivity and selectivity), for which the $10^{-3}$ dilution was selected in each standard curve, and DNA negative control. For each assay, the three samples were simultaneously tested, and no-template reactions (NTC) were included in each trial as contamination control.

The lower limit of detection, referred as analytical sensitivity (Ase), was experimentally determined and used as the limit of quantification (cutoff) in each assay, according to Caraguel et al. [31]. For this, a nPCRpositive sample was selected for each hemoparasite, and, from each of them, seven serial dilutions, from $10^{6}$ $\mathrm{CN} / \mu \mathrm{L}$ to $10^{-1} \mathrm{CN} / \mu \mathrm{L}$, were done. Five replicas of each dilution were amplified, and NTC were included in each trial. The cutoff was established in the $\mathrm{Cq}$ of the lowest dilution where more than $50 \%$ of the replicates amplified.

The results of the qPCR assays were compared with the standard test method (reference samples). The results were confronted in $2 \times 2$ contingency tables, and the agreement was measured using kappa coefficient (IC. 95\%). Calculation of the kappa coefficients was performed with the on-line tool VassarStats (http://vassarstats.net). The level of agreement was classified following the scale described by Landis and Koch [32]: $<0.10=$ Poor agreement; 0.20- 0.39= Fair agreement; $0.40-0.59=$ Moderate agreement; $0.60-0.79$ $=$ Substantial agreement; $0.80-1.00=$ Almost perfect agreement.

\section{Procedure to Estimate Parasitemia}

The parasitemia was estimated in the reference samples that resulted positive by the GPCR, for each protozoan. The initial target DNA copy number in each sample $(\mathrm{CN} / \mu \mathrm{L})$ was calculated based on $\mathrm{Cq}$ value with the program Bio-Rad CFX96 Manager v. 3.1 (BioRad). Afterwards, the number of parasites per $\mathrm{mL}$ of blood was estimated with the formula proposed by Ros- 
García et al. [33] with modifications: $P=C N / \mu L\left(V_{B} / V_{E X}\right)$ $\left(V_{E L} / V_{T}\right)(1 / C N)$, where: $P$ - is the number of parasites per $\mathrm{mL}$ of blood, $\mathrm{V}_{\mathrm{B}^{-}}$volume of reference blood $(1 \mathrm{~mL})$, $V_{E X}$ volume of blood for extracting DNA $(200 \mu \mathrm{l}), V_{E L}=$ DNA elution volume $(100 \mu \mathrm{l}), \mathrm{V}_{\mathrm{T}}$-volume of DNA in the $\mathrm{PCR}$ reaction, and $\mathrm{CN}$ - the gene copy number. For $\mathrm{CN}$, 100 copies of the gene $m t-C y t b$ were considered, according to Salem et al. [34].

Subsequently, the percentage of infected erythrocytes per $\mathrm{mL}$ of blood $(\mathrm{IRBC} / \mathrm{mL})$ was calculated by the equation: IRBC/mL (\%) = P/ (MI x RBC) x 100, where $\mathrm{Ml}$ - number of merozoites in an erythrocyte, and RBC- average erythrocytes per $\mathrm{mL}$ of blood. For the MI, two parasites per cell were considered [5], and for RBC, a value of the reference in buffaloes of $7.06 \pm 0.07 \times 10^{6} \mathrm{E} / \mu \mathrm{L}$ was considered [35].

\section{RESULTS AND DISCUSSION}

The concentration of the recombinant plasmids was $479.6 \mathrm{ng} / \mu \mathrm{L}$ for $B$. bovis and $200.2 \mathrm{ng} / \mu \mathrm{L}$ for $B$. bigemina; therefore, the serial dilutions used in the standard curves $\left(10^{-2}\right.$ a $\left.10^{-8}\right)$ showed a copy number of target DNA in the ranges $1.4 \times 10^{9}-1.4 \times 10^{3} \mathrm{CN} / \mu \mathrm{L}$ for B. bovis and $5.8 \times 10^{8}-5.8 \times 10^{2} \mathrm{CN} / \mu \mathrm{L}$ for $B$. bigemina.

Both qPCR reaction assays were more efficient with a hybridization temperature of $60^{\circ} \mathrm{C}$ for $45 \mathrm{seg}$ and primer concentrations between $0.4 \mu \mathrm{M}$ and $0.8 \mu \mathrm{M}$; it was decided to use $0.4 \mu \mathrm{M}$ of each primer since this is the minimum effective concentration according to Bustin and Nolan [36]. Besides, both assays operated correctly with $2 \mu \mathrm{L}$ and $4 \mu \mathrm{L}$ of template DNA solution, but with $1 \mu \mathrm{L}$, uniformity decreased in the replicas of the least concentrated dilutions, possibly due to the reduction of the probabilities to place the target DNA in the PCR reaction, a phenomena known as "monte carlos effect" [36]. Two microliters of template DNA were selected for both assays; however, up to $4 \mu \mathrm{L}$ can be used, what contributes to the assay accuracy at low levels of parasitemia in carrier hosts, especially for $B$. bovis $[2,9]$.

The two qPCR reaction assays showed a good linearity performance, according to the amplification of the standard curve (Figure 1). In ten trials, the $\mathrm{R}^{2}$ values remained between $98 \%$ and $100 \%$ in both assays, the slope remained at $-3.28 \pm 0.15$ in the $B$. bovis assay and $-3.30 \pm 0.13$ for $B$. bigemina, corresponding to efficiencies within a range of $95 \%$ $100 \%$, and the $y$-intercepts values were of $42 \pm 4$ cycles for $B$. bovis and of $43 \pm 3$ for $B$. bigemina. These results were considered as satisfactory since the ideal efficiency in a qPCR reaction is $100 \%$ (slope $-3,32$ ), but $90-110 \%$ is acceptable [27, 35]; besides, the ten samples of carrier buffaloes examined for each assay showed the $\mathrm{Cq}$ between the $10^{-3}$ and $10^{-7}$ standard dilutions (data not shown).

During this standardization step, it was observed that the amplicons of the qPCR assays presented the melting peaks at $78.5^{\circ} \mathrm{C}$ in $B$. bigemina and at $79.5^{\circ} \mathrm{C}$ in $B$. bovis, which allowed differentiating the amplicons of unspecific bindings and primer dimers. These results were not in agreement with the results reported by Buling et al. [22], who recorded different values and $2^{\circ} \mathrm{C}$ of difference between the melting peaks $(74.15 \pm$ $0.18^{\circ} \mathrm{C}$ for $B$. bigemina and $76.4 \pm 0.21^{\circ} \mathrm{C} \pm$ for $B$.
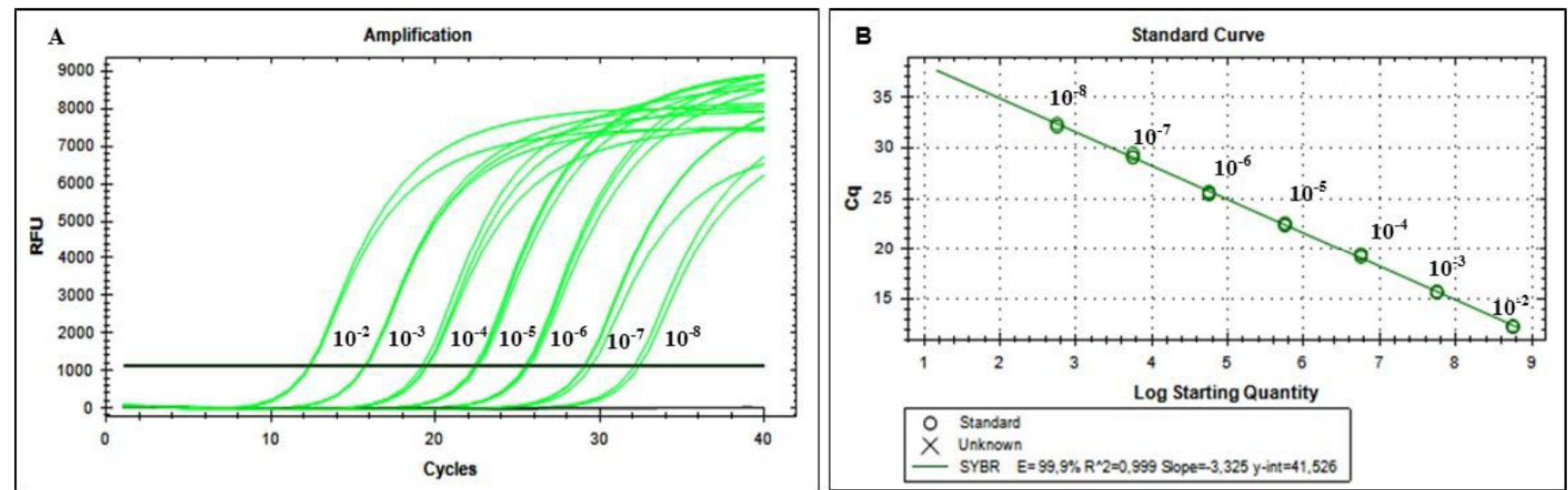

Figure 1: Linear range of the qPCR assay for B. bovis. A. Real-time PCR fluorescence curves derived from serially diluted standard concentration (plasmid copy number); each plot corresponds to seriated dilution in the standard curve, ranging from $10^{-2}$ to $10^{-8}$, the $y$-axis indicates the fluorescence intensity, and the automatic threshold line (1000) indicates the threshold cycle $(\mathrm{Cq})$ of each standard dilutions (in triplicate). B. Regression curve generated by plotting the mean Cq values as a function of the starting copy number (Log) of the standard dilutions, showing the PCR reaction efficiency $(E)$, correlation coefficient $\left(R^{2}\right)$, Slope and y-intercept. Automatically generated graphics by the software Bio-Rad CFX96 Manager v. 3.1 (BioRad). 
Table 1: Intra- and Inter-Assay Repeatability of the qPCR Assays for B. bovis and B. bigemina

\begin{tabular}{|c|c|c|c|c|c|c|}
\hline \multirow{2}{*}{$\begin{array}{c}\text { Standard curves } \\
\text { dilutions }\end{array}$} & \multicolumn{3}{|c|}{ qPCR- B. bovis } & \multicolumn{3}{|c|}{ qPCR- B. bigemina } \\
\hline & $\begin{array}{c}\mathrm{Cq} \\
\text { means }\end{array}$ & $\begin{array}{c}\text { Inter-assays CV } \\
(\%)\end{array}$ & $\begin{array}{c}\text { Intra-assays CV } \\
(\%)\end{array}$ & $\mathrm{Cq}$ & $\begin{array}{c}\text { Inter-assays CV } \\
(\%)\end{array}$ & $\begin{array}{c}\text { Intra-assays } \\
\text { CV (\%) }\end{array}$ \\
\hline $10^{-2}$ & 12.4 & 2.3 & 0.4 & 11.2 & 1.6 & 0.7 \\
\hline $10^{-3}$ & 16.6 & 3.8 & 0.5 & 14.4 & 1.1 & 0.6 \\
\hline $10^{-4}$ & 19.6 & 2.8 & 0.8 & 17.9 & 1.7 & 0.8 \\
\hline $10^{-5}$ & 22.8 & 3.2 & 0.5 & 20.3 & 0.2 & 0.4 \\
\hline $10^{-6}$ & 26.2 & 3.2 & 0.3 & 24.6 & 0.6 & 0.2 \\
\hline $10^{-7}$ & 29.3 & 2.1 & 0.5 & 28.3 & 1.5 & 1.1 \\
\hline $10^{-8}$ & 32.1 & 2.1 & 1.1 & 31.0 & 1.5 & 1.6 \\
\hline
\end{tabular}

bovis) of the amplicons with these primers, maybe because different platforms and QPCR commercial mix were used. Based on the low values of the coefficient of variation between the Cqs of the standard dilutions (Table 1), the GPCR assays showed a high repeatability, which indicated that the optimization of the $\mathrm{qPCR}$ reactions was achieved [27].

The ASp of both assays was confirmed; especially, the melting curve analysis discriminated between $B$. bovis and $B$. bigemina, and those of the matrix components (host DNA) (Figure 2). The melting temperature of the nucleic acid fragment is affected by its length, GC content, and the presence of base mismatches, among other factors. The melting-curve analysis is a straightforward way to ensure reaction specificity of the real-time PCR reactions and reduces the need for the time-consuming gel electrophoresis [36]. Furthermore, performing both assays with the same thermocycling parameters confirmed the feasibility of the system as multiple qPCR, allowing the specific diagnosis of the two protozoan parasites in several samples in a single qPCR run.

The ASe was similar in both assays, established in 20 DNA copies $(\mathrm{CN} / \mu \mathrm{L})$, so the cutoff was located in the $\mathrm{Cq} 38$ (Figure 3 ). This methodology to select the cutoff allows reducing the number of replicates to predict the minimum concentration of the target DNA in which more than $50 \%$ of the samples will be detected; specifically, five replicates per dilution allows to estimate with $95 \%$ confidence [31]. The results indicate that the assays allow detecting and quantifying even a parasite on the sample $(300 \mu \mathrm{L}$ of blood) because the gene $m t-C y t b$ can be found about 100 times in each parasite of Babesia spp. [34].

In the analysis of the diagnostic performance of the qPCR assays against samples diagnosed by $\mathrm{nPCR}$, a kappa coefficient of 0.63 was obtained for $B$. bovis and $\mathrm{k}=0.80$ for $B$. bigemina (Table 2), so the agreement was evaluated as substantial. The differences were
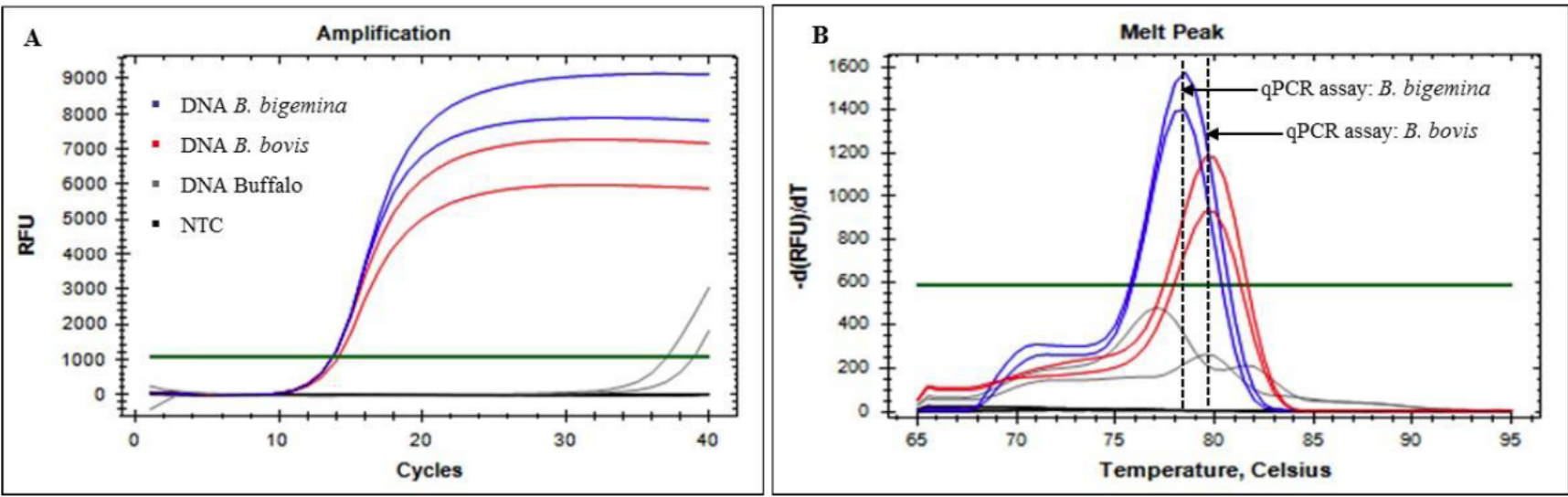

Figure 2: Analytical specificity of the qPCR assays. A. Real-time PCR fluorescence curves derived from DNA standard dilution $\left(10^{-3}\right)$ in the standard curve of $B$. bovis and B. bigemina (positive control), water buffalo genomic DNA (negative control), NTCno template control, each sample in duplicate. B. Melting curve analysis. B. bigemina and B. bovis amplicons (only obtained in the corresponding assay) are distinguished by the difference of approximately $1^{\circ} \mathrm{C}$ in their melting peak. Automatically generated graphics by the software Bio-Rad CFX96 Manager v. 3.1 (BioRad). 

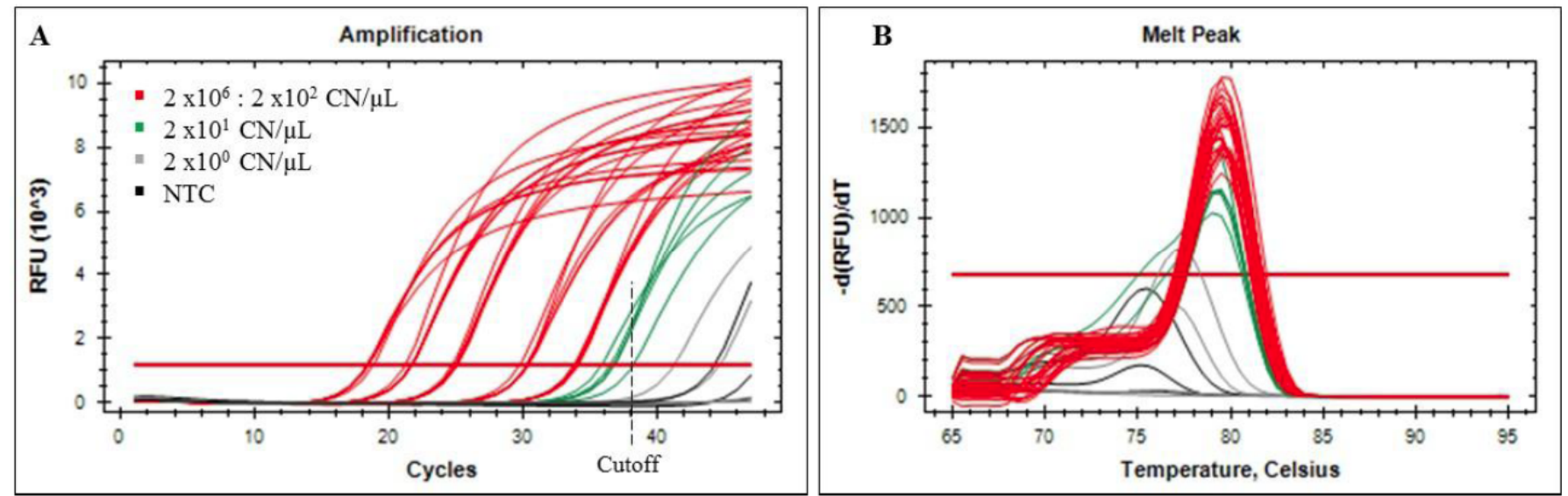

Figure 3: Analytical sensitivity and cutoff of the qPCR assay for $B$. bovis. A. Real-time PCR fluorescence curves derived from a serially diluted DNA reference sample; each plot corresponds to DNA dilution (in quintuplicate) in the range from $20 \times 10^{6}$ to 2 $\mathrm{CN} / \mu \mathrm{L}$; NTC- no template control. The detection limit was established in $20 \mathrm{CN} / \mu \mathrm{L}$ (green), indicating the corresponding Cq cutoff (38). B. Melting curve analysis of resulting B. bovis amplicons. Automatically generated graphics by the software Bio-Rad CFX96 Manager v. 3.1 (BioRad).

essentially in the number of animals with positive diagnosis for both hemoparasites, in favor of the qPCR assays, so that $33 \%$ of the negative animal for $B$. bovis by $\mathrm{nPCR}$ resulted positive by $\mathrm{qPCR}$, and $20 \%$ of the negative animals for $B$. bigemina by $\mathrm{nPCR}$ resulted positive by qPCR.

The differences could be a consequence of the number of copies of the target DNA since the nPCR assays were targeted to the gene $18 S$ rRNA, which presents three copies in the genome of Babesia spp., and the lower detection limit of these assays is equivalent to 14 parasites according to Guerrero et al. [24]. This result is independent to the fact that the QPCR and $\mathrm{nPCR}$ assays usually have similar Ase when they have the exact same target DNA $[37,38]$.

The increase of Ase of the extra chromosomal DNA based test with respect to the ribosomal DNA-based test in the diagnosis of Babesia spp. was previously reported by Salem et al. [34], who compared the conventional PCR assay and observed that the extra chromosomal DNA assays were $20 \%$ more sensitive.
Additionally, Buling et al. [22] with qPCR assays similar to those used in this work, confirmed that the analytical sensitivity was $100 \%$ higher than that in the ribosomal DNA-based assay. In correspondence, Billhassi et al. [23], with qPCR, identified Nellore cattle infected with $B$. bovis that could not be previously detected by $\mathrm{nPCR}$.

In the quantification by $\mathrm{qPCR}$, all the positive samples to $B$. bovis showed the Cq between the cycles 23 and 32 (Figure 4), corresponding to parasitemia values between 0.2 and $0.0000001 \% \mathrm{IRBC} / \mathrm{mL}$, with a mean of $0.01 \% \mathrm{IRBC} / \mathrm{mL}$. The samples positive to $B$. bigemina showed a $\mathrm{Cq}$ between 20 and 35, with a higher range of parasitemia values estimated between 5 and $0,000001 \% \mathrm{IRBC} / \mathrm{mL}$, with a mean of $0.08 \%$ $\mathrm{IRBC} / \mathrm{mL}$. These parasitemia levels are characteristic of bovines carrying these hemoparasites in endemic areas [9, 39]; so they may be sufficient for infection of feeding ticks, enabling the biological transmission of these protozoa from carriers buffalos, however the infectiousness of these hosts should be analyzed in future research.

Table 2: Agreement between the Results of the qPCR and nPCR Assays

\begin{tabular}{|c|c|c|c|c|}
\hline \multirow{2}{*}{ nPCR $^{*}$} & \multicolumn{2}{|c|}{ qPCR- B. bovis } & \multicolumn{2}{c|}{ qPCR- B. bigemina } \\
\cline { 2 - 5 } & $(+)$ & $(-)$ & $(+)$ & 30 \\
\hline$(+) 30$ & 29 & 20 & 6 & 24 \\
\hline$(-) 30$ & 10 & 21 & 36 & 24 \\
\hline Total & 39 & \multicolumn{2}{|c|}{$0.80(0.65-0.94) ; 0.07$} \\
\hline
\end{tabular}

*Identifies the panel of reference samples selected by the nPCR results. 

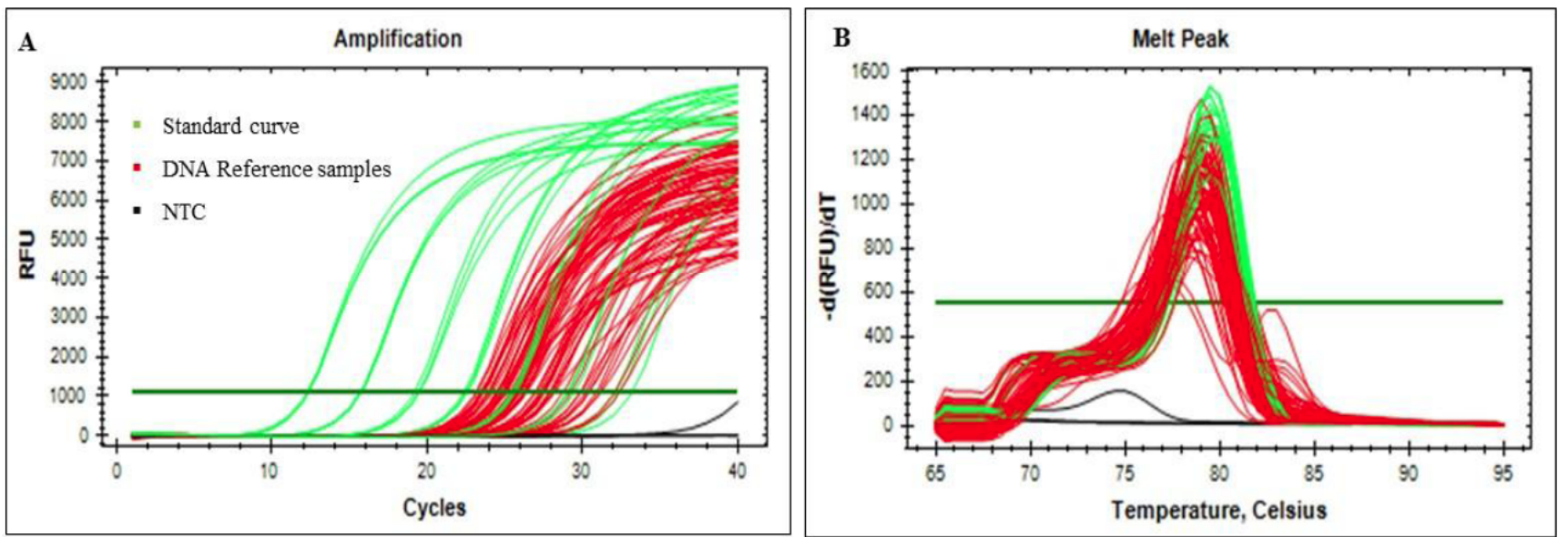

Figure 4: Analysis of the reference samples by qPCR assay for $B$. bovis. A. Real-time PCR fluorescence curves derived from a standard curve (green) and DNA reference sample (red), each sample and standard dilution in duplicate, NTC- no template control. B. Melting curve analysis of resulting $B$. bovis amplicons. Automatically generated graphics by the software Bio-Rad CFX96 Manager v. 3.1 (BioRad).

Low-level parasitemia in cattle characterizes the balanced interaction among hosts, hemoparasites and vectors, which assures the persistence in the hosts and the endemic stability in the herds. On the contrary, high parasitemia and clinical symptoms appear when there is no compensation between pathogen virulence and host resistance [3]. These results confirm that water buffalo offers natural resistance to $B$. bovis and $B$. bigemina [10, 40]. Further studies must be conducted to confirm the capacity of carrier buffaloes of infecting tick populations and their contribution to the epidemiological process of the bovine babesiosis.

\section{CONCLUSIONS}

The standardized SYBR Green based real-time PCR system, targeting the extra chromosomal mt-Cytb gene, allowed the sensitive detection and quantification of $B$. bovis and $B$. bigemina, and its usefulness under field conditions was confirmed with water buffalo blood samples. This qPCR system provides quantitative data of the parasitemia levels what should contribute to measure the host competence and reservoir capacity of water buffaloes for these protozoa.

\section{CONFLICTS OF INTEREST}

None of the authors has a financial or personal relationship with other people or organizations that could inappropriately influence the content of the paper.

\section{ACKNOWLEDGEMENTS}

This work was supported by funding from Conselho Nacional de Desenvolvimento Científico e Tecnológico
(CNPq-474648/210-9), Brazil; Empresa Brasileira de Pesquisa Agropecuária (Embrapa Pecuária Sudeste); and the National Priority Program for Animal and Plant Health, Ministry of Agriculture (MINAGRIP131LH003007), Cuba. Dasiel Obregon wishes to acknowledge the Coordination for the Improvement of Higher Education Personnel (CAPES), Brazil, for his sandwich PhD grant (Capes/MES- Docentes, 2013). We are grateful to Eduardo Sistachs Rodríguez and anonymous reviewers for their constructive feedback, which greatly improved this paper.

\section{REFERENCES}

[1] Suarez CE, Noh S. Emerging perspectives in the research of bovine babesiosis and anaplasmosis. Vet Parasitol 2011; 180(1-2): 109-125. http://dx.doi.org/10.1016/j.vetpar.2011.05.032

[2] OIE. Babesiosis bovina. In: Manual of Diagnostic Tests and Vaccines for Terrestrial Animals 2012. Paris, France: World Organization for Animal Health 2012; 1-16.

[3] Jonsson NN, Bock RE, Jorgensen WK, Morton JM, Stear MJ. Is endemic stability of tick-borne disease in cattle a useful concept? Trends Parasitol 2012; 28(3): 85-89. http://dx.doi.org/10.1016/j.pt.2011.12.002

[4] Goff WL, Johnson WC, Molloy JB, et al. Validation of a competitive enzyme-linked immunosorbent assay for detection of Babesia bigemina antibodies in cattle. Clin Vaccine Immunol 2008; 15(9): 1316-1321. http://dx.doi.org/10.1128/CVI.00150-08

[5] Bock R, Jackson L, Vos A, Jorgensen W. Babesiosis of cattle. Parasitology 2004; 129 (7): S247-S269. http://dx.doi.org/10.1017/S0031182004005190

[6] Cantu A, Ortega-S JA, Mosqueda J, Garcia-Vazquez Z, Henke SE, George JE. Immunologic and molecular identification of Babesia bovis and Babesia bigemina in freeranging white-tailed deer in northern Mexico. J Wildl Dis 2007; 43(3): 504-507.

http://dx.doi.org/10.7589/0090-3558-43.3.504

[7] Iseki $\mathrm{H}$, Alhassan $\mathrm{A}$, Ohta $\mathrm{N}$, et al. Development of a multiplex loop-mediated isothermal amplification (mLAMP) 
method for the simultaneous detection of bovine Babesia parasites. J Microbiol Methods 2007; 71(3): 281-287. http://dx.doi.org/10.1016/j.mimet.2007.09.019

[8] Obregón D, Oliveira MCS, Tizioto $P$, et al. Diagnóstico de Babesia bovis en búfalos de la región occidental de Cuba a través de un ensayo de nPCR. Rev Salud Anim 2012; 34(2): 101-108.

[9] Chauvin AC, Oreau EM, Onnet SB, et al. Babesia and its hosts: adaptation to long-lasting interactions as a way to achieve efficient transmission. Vet Res 2009; 40(2): 37. http://dx.doi.org/10.1051/vetres/2009020

[10] Terkawi MA, Huyen NX, Shinuo $C$, et al. Molecular and serological prevalence of Babesia bovis and Babesia bigemina in water buffaloes in the northeast region of Thailand. Vet Parasitol 2011; 178(3-4): 201-207. http://dx.doi.org/10.1016/j.vetpar.2011.01.041

[11] Silva JB, André MR, da Fonseca AH, et al. Molecular and serological prevalence of Babesia bovis and Babesia bigemina in water buffaloes in the north region of Brazil. Vet Parasitol 2013; 197(3-4): 678-681. http://dx.doi.org/10.1016/j.vetpar.2013.05.020

[12] Benitez D, Cetrá B, Florin-christensen M. Rhipicephalus (Boophilus) microplus ticks can complete their life cycle on the water buffalo (Bubalus bubalis). J Buffalo Sci 2012; 1(2): 193-197. http://dx.doi.org/10.6000/1927-520X.2012.01.02.11

[13] Obregón D, Rodríguez JD, Roque E, Alemán Y. Rhipicephalus (Boophilus) microplus (Acari: Ixodidae) en búfalos (Bubalus bubalis), en Cuba. Rev Salud Anim 2010; 32(2): 132-134.

[14] Ferreri L, Benitez D, Dominguez $M$, et al. Water buffalos as carriers of Babesia bovis in Argentina. Ann N Y Acad Sci 2008; 1149: 149-151. http://dx.doi.org/10.1196/annals.1428.036

[15] Oliveira-Sequeira TCG, Oliveira MCS, Araujo JP, Amarante FT. PCR-based detection of Babesia bovis and Babesia bigemina in their natural host Boophilus microplus and cattle. Int J Parasitol 2005; 35(1): 105-111.

http://dx.doi.org/10.1016/j.ijpara.2004.09.002

[16] Miller E, Huppert A. The effects of host diversity on vectorborne disease: The conditions under which diversity will amplify or dilute the disease risk. PLoS One 2013; 8(11). http://dx.doi.org/10.1371/journal.pone.0080279

[17] Miller E, Warburg A, Novikov I, et al. Quantifying the contribution of hosts with different parasite concentrations to the transmission of visceral leishmaniasis in Ethiopia. PLoS One $2014 ; 8(10): 1-8$

http://dx.doi.org/10.1371/journal.pntd.0003288

[18] Fahrimal Y, Goff WL, Jasmerl DP. Detection of Babesia bovis carrier cattle by using polymerase chain reaction amplification of parasite DNA. J Clin Microbiol 1992; 30(6): 1374-1379.

[19] Bose R, Jorgensen WK, Dalgliesh RJ, Friedhoff KT. Current state and future trends in the diagnosis of babesiosis. Vet Parasitol 1995; 57: 61-74 http://dx.doi.org/10.1016/0304-4017(94)03111-9

[20] Ramos CN, Araújo FR, Souza IIF, et al. Real-time polymerase chain reaction based on msa2c gene for detection of Babesia bovis. Vet Parasitol 2011; 176(1): 79-83. http://dx.doi.org/10.1016/j.vetpar.2010.10.035

[21] Kim C, Iseki H, Herbas MS, et al. Development of TaqManbased real-time PCR assays for diagnostic detection of Babesia bovis and Babesia bigemina. Am J Trop Med Hyg 2007; 77(5): 837-841.

[22] Buling A, Criado-Fornelio A, Asenzo G, Benitez D, BarbaCarretero JC, Florin-Christensen M. A quantitative PCR assay for the detection and quantification of Babesia bovis and B. bigemina. Vet Parasitol 2007; 147(1-2): 16-25. http://dx.doi.org/10.1016/j.vetpar.2007.03.031
[23] Bilhassi TB, Oliveira HN, Ibelli AM, et al. Quantitative study of Babesia bovis infection in beef cattle from São Paulo state, Brazil. Ticks Tick Borne Dis 2014; 5: 234-238. http://dx.doi.org/10.1016/j.ttbdis.2013.11.002

[24] Guerrero FD, Bendele KG, Davey RB, George JE. Detection of Babesia bigemina infection in strains of Rhipicephalus (Boophilus) microplus collected from outbreaks in south Texas. Vet Parasitol 2007; 145(1-2): 156-163. http://dx.doi.org/10.1016/j.vetpar.2006.11.014

[25] Machado RZ, Montassier HJ, Pinto A, et al. An enzymelinked immunosorbent assay (ELISA) for the detection of antibodies against Babesia bovis in cattle. Vet Parasitol 1997; 71(1): 17-26. http://dx.doi.org/10.1016/S0304-4017(97)00003-4

[26] OIE. Selection and use of reference samples and panels. In: OIE Validation Guidelines 2014. Paris, France: World Organization for Animal Health 2014; 1-9.

[27] Ke GM, Cheng HL, Ke LY, et al. Development of a quantitative Light Cycler real-time RT-PCR for detection of avian reovirus. J Virol Methods 2006; 133(1): 6-13. http://dx.doi.org/10.1016/j.jviromet.2005.09.011

[28] Mueller R, Padmabandu G, Taylor RH. Standarization of qPCR and qRT-PCR assays. In: Bustin S, ed. A- Z Quantitative PCR. La Jolla, California, USA: International University Line 2004; 577.

[29] OIE. Principles and methods of validation of diagnostic assays for infectious diseases. In: Manual of Diagnostic Tests and Vaccines for Terrestrial Animals 2014 2013th ed. Paris, France: World Organization for Animal Health 2013; 18.

[30] OIE. Developmen and optimisation of nucleic acid detection assays. In: OIE Validation Guidelines 2014. Paris, France: World Organization for Animal Health 2014; 1-11.

[31] Caraguel CGB, Stryhn H, Gagné N, Dohoo IR, Hammell KL. Selection of a cutoff value for real-time polymerase chain reaction results to fit a diagnostic purpose: analytical and epidemiologic approaches. J Vet Diagn Invest 2011; 23(1): 215.

\section{http://dx.doi.org/10.1177/104063871102300102}

[32] Landis JR, Koch GG. The measurement of observer agreement for categorical data. Biometrics 1977; 33: 159174.

http://dx.doi.org/10.2307/2529310

[33] Ros-García A, Nicolás A, García-pérez AL, Juste RA, Hurtado A. Development and evaluation of a real-time PCR assay for the quantitative detection of Theileria annulata in cattle. Parasit Vectors 2012; 5: 171

http://dx.doi.org/10.1186/1756-3305-5-171

[34] Salem GH, Liu X, Johnsrude JD, Dame JB, Roman Reddy G. Development and evaluation of an extra chromosomal DNAbased PCR test for diagnosing bovine babesiosis. Mol Cell Probes. 1999; 13(2): 107-113.

\section{http://dx.doi.org/10.1006/mcpr.1998.0223}

[35] Wills BT. Hematology of water buffalo (Bubalus bubalis). In: Weiss DJ, Wardrop KJ, eds. Schalm's Veterinary Hematology. Ed. 6th. Ames, lowa, USA: Blackwell Publishing Ltd. 2010; 927-930.

[36] Bustin A, Nolan T. Data analysis interpretation. In: Bustin A., ed. A- Z Quantitative PCR 2004th ed. La Jolla, California. USA: International University Line 2004; 378-381

[37] Bastien P, Procop GW, Reischl U. Quantitative real-time PCR is not more sensitive than conventional PCR. J Clin Microbiol 2008; 46(6): 1897-1900. http://dx.doi.org/10.1128/JCM.02258-07

[38] Kim EJ, Bauer C, Grevelding CG, Quack T. Improved PCR/nested PCR approaches with increased sensitivity and specificity for the detection of pathogens in hard ticks. Ticks Tick Borne Dis 2013; 4(5): 409-416. http://dx.doi.org/10.1016/j.ttbdis.2013.04.004 
[39] Schnittger L, Rodriguez AE, Florin-Christensen M, Morrison D. Babesia: a world emerging. Infect Genet Evol 2012; 12(8): 1788-1809.

http://dx.doi.org/10.1016/j.meegid.2012.07.004
[40] Mahmmod Y. Natural Babesia bovis infection in water buffaloes (Bubalus bubalis) and crossbred cattle under field conditions in Egypt: a preliminary study. J Arthropod-Borne Dis 2014; 8(1): 1-9.

Received on 04-07-2016

Accepted on 29-07-2016

Published on 18-08-2016

DOI: http://dx.doi.org/10.6000/1927-520X.2016.05.02.4 